\title{
Roosting behaviour of a migratory songbird on Jamaican coffee farms: landscape composition may affect delivery of an ecosystem service
}

\author{
VITEK JIRINEC, BRENT R. CAMPOS and MATTHEW D. JOHNSON
}

\begin{abstract}
Summary
Recent evidence indicates that insectivorous birds in shade coffee farms provide economically significant ecosystem services by reducing insect pests, which should encourage cultivation practices favouring birds and other wildlife. However, the provisioning of this service may be dependent on landscape composition and movement patterns of these mobile consumers. Very little information is currently available on bird movements in coffee-dominated landscapes. We examined roosting behaviour in Black-throated Blue Warblers Dendroica caerulescens on two Jamaican coffee farms using radio telemetry in order to determine whether birds commute between nocturnal roosts and diurnal foraging ranges in coffee habitat. Nocturnal tracking revealed most birds moved outside diurnal foraging ranges on the farms to roost in forested habitat patches, sometimes up to $1 \mathrm{~km}$ away. Of 42 roost locations, only eight roosts were within the coffee farm perimeter: one individual in a coffee bush, and seven others in shade trees or vegetated riparian strips. Logistic regression confirmed that birds strongly selected continuous forest and individual trees over coffee for roosting. These findings reflect the ecological connectivity between coffee habitats and the adjacent landscape and raise the possibility that the provisioning of pest reduction services could be at least partly dependent on a farm's proximity to forest patches.
\end{abstract}

\section{Introduction}

Recent research (Kellermann et al. 2008, Johnson et al. 2010) indicated that ecosystem services provided by birds found on coffee farms can lead to economically significant reduction of coffee berry borer Hypothenemus hampei infestation. In Jamaica, this reduction of the world's primary coffee pest resulted in an increased coffee crop yield valued at over US \$4,0oo across a 62.6 ha study area in high-elevation coffee farms (Kellermann et al. 2008). This amount is near Jamaica's average per capita gross national income $(\$ 5,241$; United Nations Statistics Division 2010). A study in a middle-elevation Jamaican coffee farm found a yet stronger effect of birds on borer infestation, totalling US $\$ 5,495$ over 18 ha (Johnson et al. 2010).

However, the provisioning of this ecosystem service may be dependent on landscape composition as well as the movement of these mobile consumers (Kremen et al. 2007, Kellerman et al. 2008, Luck et al. 2009). In Jamaica, coffee farms are typically small $(<100$ ha) and occur in complex landscapes composed of residual and regenerating forest patches, mixed agriculture, and rural housing with associated gardens and horticulture. Very little information is currently available on movement patterns of birds in and around coffee farms.

Recent evidence suggests that some wintering Nearctic-Neotropical migratory songbirds utilise nocturnal roost sites that do not spatially overlap with their respective diurnal home ranges (Smith et al. 2008). This type of roosting behaviour has been confirmed for Prothonotary Warbler 
Protonotaria citrea (Warkentin and Morton 1995) and Northern Waterthrush Seiurus noveboracensis (Reitsma et al. 2002, Burson et al. 2005, Hunt et al. 2005). In addition, anecdotal observations of unmarked migrants moving away from diurnal activity areas at dusk suggest commutes to nocturnal roost locations for several other species (Smith et al. 2008), including Gray Catbird Dumetella carolinensis (Alsop 1995), Northern Parula Parula americana, Cape May Warbler Dendroica tigrina, Prairie Warbler Dendroica discolor (Stacier 1992, Baltz 2000, Latta 2003), and Palm Warbler Dendroica palmarum (Latta 2003). Still needed are in-depth, within-species studies that describe the basic ecology of roosting behaviour and quantify its prevalence in individually marked birds (Smith et al. 2008). Roosting behaviours have conservation implications because multiple habitats may require protection for species that roost in habitats separate from their diurnal activities (Brown and Sherry 2008). The theoretical importance of roost site selection to ecosystem services and conservation coupled with a general lack of knowledge pertaining to wintering migrant night roosts should encourage more attention. We used radio telemetry to test the hypothesis that birds commute between nocturnal roosts and diurnal foraging ranges in coffee habitat.

\section{Methods}

\section{Study species}

Many species of non-flocking migrant passerines establish resource-based territories that are defended for at least part of the wintering season (Brown et al. 2000), including Black-throated Blue Warblers Dendroica caerulescens in Jamaica (Holmes et al. 1989).

The Black-throated Blue Warbler breeds in south-eastern Canada through the north-eastern United States and migrates along the eastern seaboard to the Caribbean, where it winters in forested habitats of the Greater Antilles from Puerto Rico to Cuba, Jamaica, and Hispaniola, with some birds in the Bahamas and a few along the Yucatán coast and Belize (Holmes et al. 2005). Stable isotope study suggests that birds wintering in Jamaica come from the northern portion of the breeding range in Canada, from southern Ontario to southern Québec (Rubenstein et al. 2002).

The warbler has been reported as the most significant potential coffee berry borer predator in high-elevation coffee farms in eastern Jamaica (Kellermann et al. 2008, Sherry et al. unpubl. data), and was the most frequently captured understorey-foraging insectivore in the farms used in this study (S. Wadham unpubl. data).

\section{Study areas}

Our study sites were located in western Jamaica on two privately-owned coffee farms. The Seven Rivers farm ( $56 \mathrm{ha}$ ) is located near Montpelier, St. James ( $140 \mathrm{~m} ; 18^{\circ} 2 \mathrm{O}^{\prime} \mathrm{N}, 77^{\circ} 55^{\prime} \mathrm{W}$ ). Kew Park farm ( $18 \mathrm{ha}$ ) is near Betheltown, Westmoreland ( $300 \mathrm{~m} ; 18^{\circ} 15^{\prime} \mathrm{N}, 77^{\circ} 56^{\prime} \mathrm{W}$ ).

The Seven Rivers farm is uniformly flat, but the area outside the farm perimeter rises sharply to steep limestone hillsides with young second growth forest. While the midstorey is relatively open in the forest, abundant vines create a complex network of suspended vegetation. Within the farm, coffee Coffea arabica is grown with banana Musa sp. and coconut Cocos nucifera over most of the farm area, which is shaded by various tree species including Inga vera, Leucaena glauca and Ceiba pentandra. The western side of Seven Rivers contains a small $(<10$ ha) citrus orchard. Several small rivers include narrow $(<50 \mathrm{~m})$ riparian strips composed of various trees and shrubs, especially Hibiscus elatus, Spathodea campanulata, Cedrela odorata and Gliricidia sepium.

Kew Park is a farm with varied topography and coffee interspersed on gentler slopes. As in Seven Rivers, forested areas outside Kew Park's perimeter are characterised by a karst landscape containing steep limestone hills covered in second growth forest and jagged rocks, linked to an upper canopy with a dense tangle of thin vines. Dominant species include Bumelia sp., Brosimum 
alicastrum and Calophylum jacquinii. Pasture, agricultural fields and rural housing are present in the east and south-east of the farm. Approximately $70 \%$ of the farm is shaded by Cedrela odorata, Swietenia mahagoni, Ceiba pentandra, Terminalia latifolia, Inga vera, Mangifera indica, Ficus spp. and various fruit trees typically $8-15 \mathrm{~m}$ in height.

\section{Data collection}

In December 2008-January 2009 we captured warblers using mist nets $(12 \times 2.6 \mathrm{~m}, 30 \mathrm{~mm}$ mesh size) distributed throughout the study farms. We attached radio transmitters (o.35 g, LB-2N Holohil Systems Ltd., Carp, ON, Canada) using eyelash glue (DUO eyelash adhesive, American International Ind., USA; Sekercioglu et al. 2007) to 24 warblers weighing $\geq 8.7 \mathrm{~g}$ (corresponding to radio weight $\leq 5 \%$ of body weight). In addition to the transmitter, each bird was fitted with a standard USGS aluminium band and a unique colour-band combination. Age and sex determination of captured birds were based on plumage colour and morphometric measurements (Pyle 1997). Each individual was measured (wing chord and wing patch) and weighed to the nearest $0.1 \mathrm{~g}$ using an Ohaus ${ }^{\circledR}$ scale.

To allow the birds time to adjust to the transmitter, we started tracking the day following capture. Diurnal and nocturnal radio-tracking was conducted using three-element Yagi antennas equipped with either a Wildlife Materials TRX-200oS or Communication Specialists R-10oo receiver. Birds were tracked from sunrise to sunset to construct diurnal foraging home ranges. We obtained 2-8 diurnal locations per bird per day (mean $=4.4$ ) for $7-10$ days, yielding 30-40 total locations per bird $($ mean $=34.5)$. Three birds exhibited abnormal behaviour following transmitter attachment, such as strongly reduced movement and weak flight, erratic signal strength, or early signal cessation. In these cases we suspected stress from handling, faulty transmitter attachment, or battery failure, so these individuals were excluded from the study, yielding 21 birds with complete data. Following the data-gathering period, five uniquely colour-marked and radiotracked individuals were observed without transmitters, indicating at least some transmitters fell off prior to migration.

\section{Roost search}

We refer to "roost" as a geographic location where a bird spends night-time hours, regardless of whether it rests solitarily or with other individuals. We obtained two roost locations for each of the 21 radio-tagged birds. Following the location of an initial roost, we acquired a second roost location for each bird between one and three nights later. Starting one hour after sunset, a roost location was determined by homing in directly on a bird to within a $5 \mathrm{~m}$ diameter area. Out of 42 locations, direct visual observation of the birds was not possible in most cases $(n=35)$ due to dense vegetation and invariant signal strength within $5 \mathrm{~m}$ of the bird. Upon detection of a roosting bird or closest possible area, we georeferenced the location using a Garmin GPSmap 60 Cx GPS unit and flagged the location for subsequent vegetation measurements.

\section{Habitat quantification}

Habitat measurements were taken, centred on the roost site. To remove possible personal biases in the precise location of estimated roost placement for locations without visual confirmation, we used a short random distance and bearing $\left(\mathrm{o}-3 \mathrm{~m}, \mathrm{O}-360^{\circ}\right.$, respectively) from our estimate of the bird location as the centre of the plot. Vegetation density was evaluated using the "stacked cube" method (Kus 1998). We determined the percent volume filled by vegetation in a threedimensional cuboid space with a $2 \times 2 \mathrm{~m}$ base standing $6 \mathrm{~m}$ high. We further divided the cuboid into three equal sections: $0-2 \mathrm{~m}, 2-4 \mathrm{~m}, 4-6 \mathrm{~m}$, and visually estimated the percentage filled by forbs, grass, woody plants, tree trunk, and coffee. We recorded the distance and diameter 
at breast height $(\mathrm{DBH})$ of the three nearest trees and estimated canopy cover using a concave spherical densiometer (Forestry Suppliers Inc. Jackson, MS, USA) at each of the cardinal directions while standing in the center of the plot. We defined trees as any woody, non-coffee plant with a DBH of at least $3 \mathrm{~cm}$.

To describe the farm area where the birds were captured and the majority of their diurnal habitat occurred, we used GIS software to systematically distribute 226 locations, $40 \mathrm{~m}$ apart, throughout the two study farms (98 in Kew Park and 128 in Seven Rivers). We located these points with a GPS and collected the same data as at roost sites.

\section{Analyses and statistical methodology}

Diurnal home ranges were constructed using minimum convex polygons (MCPs) created with the Hawth's Tools extension (v.3) in ArcGIS version 9.2 (ESRI, Redlands, CA). A one-tailed $t$-test was used to determine whether the mean distance from roosts to the nearest edge of the diurnal home range was greater than $\mathrm{m}$, and whether the mean distance from roosts to nearest farm perimeter was greater than $\mathrm{om}$. Roost locations within the home range or farm were assigned values of o for distance to home range or farm, respectively. We defined the "farm perimeter" as the area delineated by the last coffee shrubs at the edge of the farm (i.e. coffee perimeter). Data were transformed using natural log to normalise for analysis.

We estimated a resource selection function with logistic regression (RSF; Manly et al. 2002) to test whether birds selected forest and shade trees over coffee habitat. RSF compares resource attributes at used points (roost locations) to available points (randomly distributed). Consistent with most RSF analyses (Manly et al. 2002), we treated each location (two per bird) as a used data point because they were obtained at least 24 hours apart and changed for most birds from night to night (see Results), indicating that the process of selection was occurring each night. To constrain the distribution of random points to be biologically relevant, we created buffer zones around each home range. We chose buffer distances for home ranges in each of the two farms separately, using the average distance commuted to roosts by all birds within the respective farm (Kew Park $=78 \mathrm{~m}$, Seven Rivers $=119 \mathrm{~m}$, excluding a strong outlier of $950 \mathrm{~m}$ ). For each bird, we then randomly distributed points at a density of five points per hectare in the area comprising its home range and the associated home range buffer zone. We classified each roost and random location into one of five vegetation categories: coffee, continuous forest, tree (individual trees and shade trees), grassland (including pastures), and urban areas (roads and buildings). Classification was completed manually in ArcGIS based on aerial photography. We assumed that grassland and urban points were biologically not available for roosting; thus only points in continuous forest, individual trees, and coffee were used in the analysis. In all, we compared 1,033 (available) random points to 42 (used) roosts.

\section{Results}

Average distance between the two roost locations indentified per individual in Kew Park and Seven Rivers was $25 \mathrm{~m}$ and $53 \mathrm{~m}$, respectively (range o to $155 \mathrm{~m}$ ), indicating that roost selection can occur nightly.

Despite coffee comprising the majority of the warbler's diurnal home range, only one nocturnal roost $(2 \%)$ was located in a coffee shrub. This bird roosted outside the farm area during the following tracking night. Fourteen $(33 \%)$ roosts were found within their respective diurnal home ranges and eight (19\%) were located within the perimeter of a farm. Four of the eight roosts positioned within farm boundaries, however, occurred in non-cultivated spaces such as expansive shade trees or vegetated riparian strips (Table 1 ).

Mean distance from roost to diurnal home range was $119 \pm 27 \mathrm{~m}$ and was significantly larger than zero $(P<0.0001, t=4.46, \mathrm{df}=41)$. Mean roost distance to farm perimeter was $62 \pm 17 \mathrm{~m}$, 
Table 1. Nocturnal roost location summary for Black-throated Blue Warbler Dendroica caerulescens in Kew Park and Seven Rivers farms in western Jamaica.

\begin{tabular}{|c|c|c|c|c|c|c|c|c|}
\hline Farm & $\begin{array}{l}\text { birds } \\
\text { tracked } \\
\text { to roosts }\end{array}$ & $\begin{array}{l}\text { total } \\
\text { roost } \\
\text { locations }\end{array}$ & $\begin{array}{l}\text { roosts } \\
\text { within } \\
\text { home range }\end{array}$ & $\begin{array}{l}\text { roosts } \\
\text { within } \\
\text { farm }\end{array}$ & $\begin{array}{l}\text { roosts } \\
\text { in coffee } \\
\text { bush }\end{array}$ & $\begin{array}{l}\text { roosts } \\
\text { in shade } \\
\text { tree }\end{array}$ & $\begin{array}{l}\text { roosts in } \\
\text { non-cultivated } \\
\text { space }\end{array}$ & $\begin{array}{l}\text { roosts } \\
\text { within } \\
\text { forest }\end{array}$ \\
\hline Kew Park & 10 & 20 & $9(45 \%)$ & $4(20 \%)$ & o $(0 \%)$ & $2(10 \%)$ & $2(10 \%)$ & $16(80 \%)$ \\
\hline Seven Rivers & 11 & 22 & $5(23 \%)$ & $4(10 \%)$ & $1(5 \%)$ & $1(5 \%)$ & $2(9 \%)$ & $18(81 \%)$ \\
\hline Total & 21 & 42 & $14(33 \%)$ & $8(19 \%)$ & I $(2 \%)$ & $3(7 \%)$ & $4(10 \%)$ & $34(81 \%)$ \\
\hline
\end{tabular}

indicating that on average, birds roosted a significant distance outside the farm perimeter $(P<$ $0.0001, t=3.62, \mathrm{df}=41$ ).

Logistic regression analysis confirmed birds strongly selected continuous forest $(\beta=3.61 \pm$ 1.02) and individual trees $(\beta=3.23 \pm 1.10)$ over coffee for roosting. Thirty-four of 42 observed roosts $(81 \%)$ were positioned in the forest outside the farm perimeter. This trend was apparent both in Kew Park and Seven Rivers farms (Figure 1). We did not attempt to quantify the timing of movement to and from roost sites, but anecdotal observations suggest that departures generally occurred shortly after sunset, and were direct and rapid.

Roosting sites were physiognomically very different from diurnal home ranges. Roosts had generally closed canopy, averaging $94 \%$, while within-farm systematic vegetation surveys revealed a mean canopy cover of $36 \%$. Systematic farm surveys yielded an average nearest tree distance of $6.6 \mathrm{~m}$ and an average distance to the nearest three trees to be $10.1 \mathrm{~m}$. Average nearest

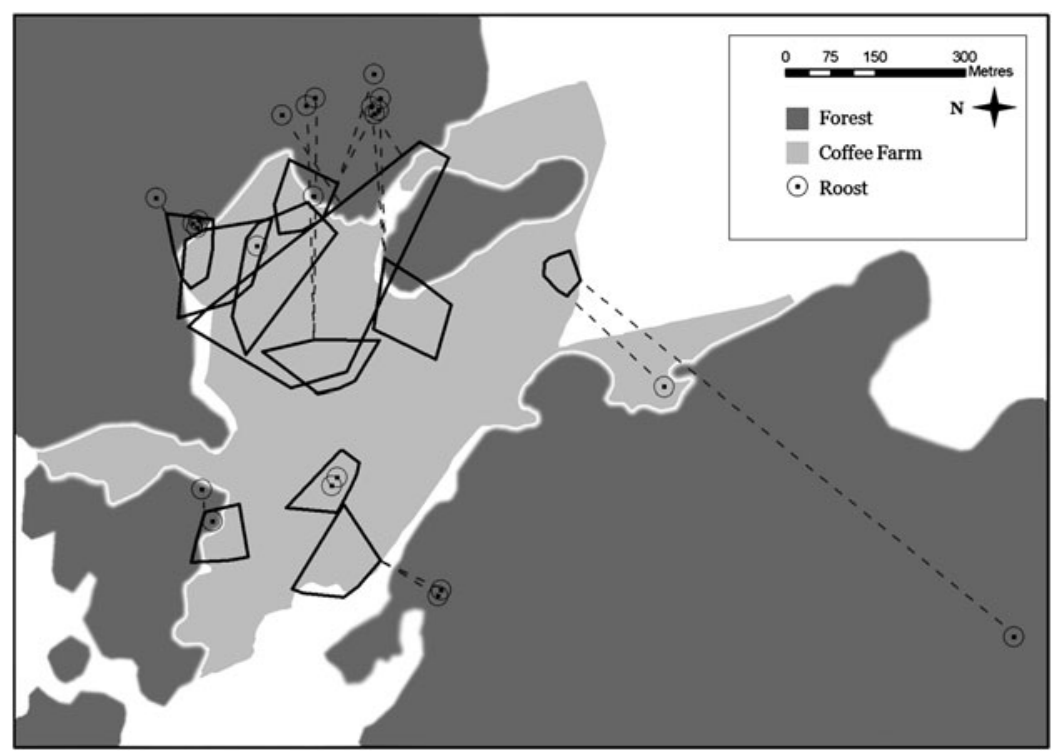

Figure 1. Black-throated Blue Warbler roosts in the Seven Rivers coffee farm in western Jamaica. Diurnal foraging ranges (black polygons) were positioned entirely or almost entirely within coffee farm perimeter. We collected two roost locations for each the 11 birds in this study area, most of which were found within the surrounding forest. All except one roost located within the farm perimeter were either in shade trees or thin forested riparian strip. Dashed lines represent the most direct path from a roost to its respective diurnal range. 
tree distance and average distance to nearest three trees in roosting areas was $1.1 \mathrm{~m}$ and $2.3 \mathrm{~m}$, respectively, indicating a much higher tree density in roosting areas.

\section{Discussion}

\section{Roosting ecology}

Black-throated Blue Warblers captured on Jamaican coffee farms strongly selected forest habitat for roosting, to which they commuted sometimes considerable distances away from their diurnal foraging ranges (Figure $\mathrm{I}$ ). All of the study birds were captured in cultivated coffee patches, where the birds spent the majority of the daytime (B. Campos unpubl. data). Quantitative studies of winter roosting of Nearctic-Neotropical migrants are limited to three species: one that roosts within its diurnal foraging range - Ovenbird Seiurus aurocapilla, and two that roost in separate habitats from their daytime activity - Prothonotary Warbler and Northern Waterthrush; Brown and Sherry 2008, Smith et al. 2008). Our study suggests Black-throated Blue Warbler can also use separate diurnal and nocturnal habitats. This project examined roosting behaviour of birds whose diurnal foraging ranges were placed largely in coffee farms. We emphasise that Blackthroated Blue Warblers with diurnal ranges in other habitats may not necessarily commute to roosting areas. To discern whether commuting behaviours are widespread, more work with migrants outside farms is needed. Due to movements to roosting sites, habitat preferences of individual birds cannot be inferred from diurnal studies or mist net data alone (Burson et al. 2005).

Although the few roosting birds we managed to see slept solitarily, our study cannot rule out the possibility of communal roosting. Seven Rivers farm contained a region where a number of individuals roosted in close proximity (Figure 1). This area was heavily dominated by an introduced species of bamboo Bambusa vulgaris with a very tall, dense and complex canopy. Interestingly, several roosts $(n=11)$ were located in bamboo. Although selection among available forested habitats was not part of our study, the birds may have selected bamboo out of proportion to its availability in the area.

Movements to roost sites appeared to be direct and rapid. In one instance, we positioned a radiotracker at a known roost location of the longest-commuting individual and another tracker near the bird's diurnal home range at dusk just before the bird's departure to roost. The signal faded quickly in the home range, and was heard shortly thereafter $\left(<_{1} \mathrm{~min}\right)$ at the roost site, $950 \mathrm{~m}$ away (Figure 1).

Because we did not track birds that typically forage in forested habitats, it is impossible to ascertain why birds foraging in coffee selected forested habitats for roosting. However, there were significant structural differences between these two habitats that could influence roosting habitat selection, and previous work has documented differences in food supply, which could influence foraging habitat selection. In this study, we found that canopy cover and tree density were much higher in roosting areas than on coffee farms. The forested areas where birds roosted were mostly composed of dense second-growth, often spread over rocky limestone hillsides. Vegetation volume in the coffee farms decreased quickly with increasing height, while the opposite was true around roost sites (Figure 2). It is possible that Black-throated Blue Warblers prefer to roost hidden in dense foliage in tree canopies, fairly high off the ground. There may also be strong differences in food supply between the forested and coffee habitats. Previous work (Johnson and Sherry 2001, Johnson et al. 2006) has shown that shade trees used in Jamaican coffee farms, especially Inga vera, have a significantly higher biomass of small foliage-dwelling arthropods than on trees in nearby wet limestone forest. Territorial behaviours in wintering Black-throated Blue Warblers (Holmes et al. 1989, Murphy et al. 2001, Smith unpubl. data) suggest intraspecific competition, likely for food. Thus, the birds in our study may have selected coffee as foraging habitat for its rich food supply, and forests as roosting habitat for its thick vegetation cover. Habitat-specific demography and measures of body condition for American Redstarts Setophaga ruticilla indicate 


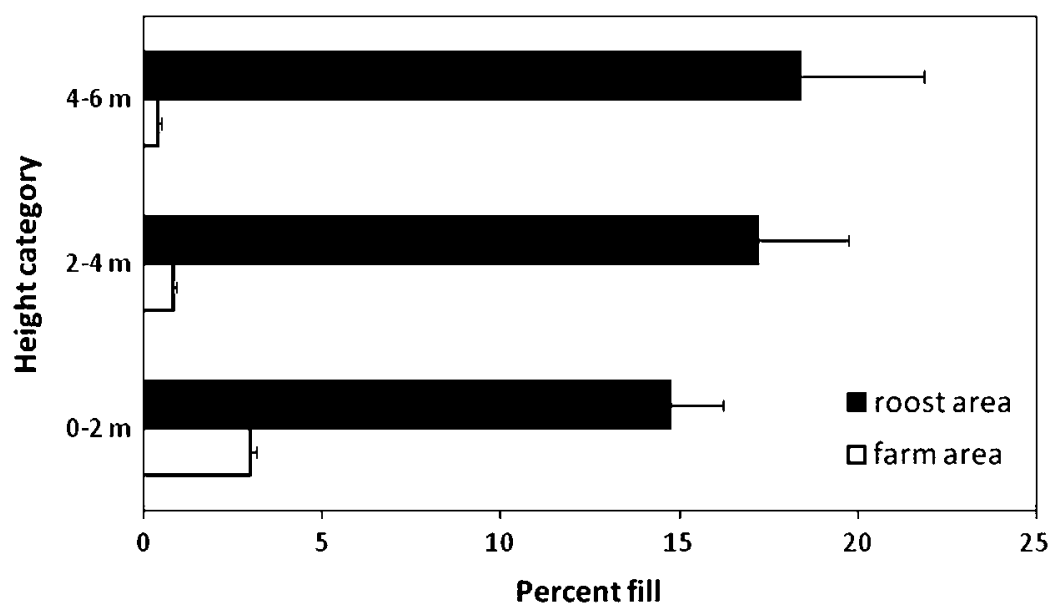

Figure 2. Mean percent vegetation fill in stacked cube columns. Columns are divided into three equal categories from the ground (o m) to the top $(6 \mathrm{~m})$ of the stacked cube, and percent cover represents the three-dimensional space filled by any woody and herbaceous plant. Farm area bars represent points $(n=226)$ systematically placed throughout each of the two study farms. Roost area bars represent locations surveyed $(n=42)$ at each roost. Error bars indicate 1.0 standard error.

that Jamaican shade coffee farms are higher in quality than some natural habitats (Johnson et al. 2006), but rigorous forest vs. coffee comparisons are not yet available for Black-throated Blue Warblers.

\section{Conservation implications}

Ecosystem services are functions of the natural environment that improve and sustain human life (Daily 1997). These services, including pest control, may be produced at a local scale by mobile organisms foraging within and between habitats (Kremen et al. 2007). Managing for ecosystem services thus requires considering habitat at the local scale as well as the larger landscape scale, which reflects both the distribution of resources as well as the movement of the agents themselves (Luck et al. 2009).

Black-throated Blue Warblers can deliver economically significant pest control services locally in coffee farms (Kellermann et al. 2008, Johnson et al. 2010). However, these services may be affected by the spatial distribution of resources at a large scale. We found that Black-throated Blue Warblers foraging in coffee habitats during the day commuted to nocturnal roost locations, often off the farm in surrounding forested habitat. Although our results do not confirm that the birds require adjacent habitats from which to commute, or that farms beyond a certain commute threshold are unlikely to be selected for foraging, our findings do raise the possibility that ecosystem services provided by warblers may be dependent on a farm's proximity to forest where birds roost. Thus, the habitat selection and movement shown by these warblers could provide an incentive for farmers and agricultural policy makers to conserve forest patches in the landscape.

Roosting behaviours have conservation implications because multiple habitats may require protection for species that roost in habitats separate from their diurnal activities (Brown and Sherry 2008). Since coffee production coincides with biologically diverse tropical latitudes often at the cost of critical habitat loss of many life forms, making coffee farms more bird-friendly by retaining adjacent forest may mitigate biodiversity loss in general. 
Breeding bird survey data compiled from 1966 to 2000 shows a correlation between declines in the southern populations of the Black-throated Blue Warbler's breeding range and heavy deforestation in some areas where these populations are thought to winter, such as in Haiti where $<3 \%$ of forest remains (Rubenstein et al. 2002). Birds thought to winter in Jamaica and Cuba (Rubenstein et al. 2002) demonstrated little change on the breeding grounds, or even increases in abundance (Sauer et al. 2001), perhaps due in part to comparatively stable tree cover on these islands. Intensification of coffee farming practices that cause Jamaican farmers to reduce shade cover (approaching "sun coffee") or clear forest to expand their farms may reduce habitat quality and quantity for Black-throated Blue Warblers.

\section{Acknowledgements}

Funding was provided by an NSF International Research Experience for Students grant. We would like to thank Shannon Wadham, Jay Iwasaki, Dr. Michael Mesler, Jenny Hutchinson, Carol Wilson, and Brian Atkinson for valuable assistance in the field. Additional help came from Dwight Robinson (University of West Indies), Peter Williams of Kew Park farm, and Jared Wolfe.

\section{References}

Alsop, F. J. III (1995) A communal roost of gray catbirds at Eco Pond, Everglades National Park. Florida Field Nat. 23: 69.

Baltz, M. E (2000) The non-breeding season ecology of Neotropical migratory birds in the dry zone of Puerto Rico. Ph.D. dissertation, Columbia: University of Missouri.

Brown, D. R. and Sherry, T. W. (2008) Solitary winter roosting of ovenbirds in core foraging area. Wilson J. Ornith. 120: 455-459.

Brown, D. R., Stouffer, P. C. and Strong, C. M. (2000) Movement and territoriality of wintering Hermit Thrushes in southeastern Louisiana. Wilson Bull. 112: 347-35.

Burson, S. L., Reitsma, L. L. and Hunt, P. D. (2005) Conservation implication of multiple habitat use by northern waterthrushes during the nonbreeding season. J. Caribbean Ornithol. 18: 72-76.

Daily, G. C. (1997) Nature's services: societal dependence on natural ecosystems. Washington DC: Island Press.

Holmes, R. T., Rodenhouse, N. L. and Sillett, T. S. (2005) Black-throated Blue Warbler (Dendroica caerulescens), The birds of North America online (A. Poole, Ed.). Ithaca: Cornell Lab of Ornithology; Retrieved from the Birds of North America Online: http://bna.birds.cornell.edu/bna/ species/087doi:10.2173/bna.87.

Holmes, R. T., Sherry, T. W. and Reitsma, L. (1989) Population structure, territoriality and overwinter survival of two migrant warbler species in Jamaica. Condor 91: 545-561.

Hunt, P. D., Reitsma, L. R., Burson, S. L. and Steele, B. B. (2005) Spatial and temporal distribution of northern waterthrushes among nonbreeding habitats in southwestern Puerto Rico. Biotropica 37: 697-701.

Johnson, M. D. and Sherry, T. W. (2001) Effects of food availability on the distribution of migratory warblers among habitats in Jamaica, West Indies. J. Anim. Ecol. 70 : 546-56o.

Johnson, M. D., Kellermann, J. L. and Stercho, A. M. (2010) Pest reduction services by birds in shade and sun coffee in Jamaica. Anim. Conserv. 13: 140-147.

Johnson, M. D., Strong, A. M. and Sherry, T. W. (2006) Migrants in tropical bird communities: the balanced breeding limitation hypothesis. J. Avian Biol. 37: 229-237.

Kellermann, J. L., Johnson, M. D., Stercho, A. M. and Hackett, S. C. (2008) Ecological and economic services provided by birds on Jamaican Blue Mountain coffee farms. Conserv. Biol. 22: 1177-1185.

Kremen, C., et al. ( 18 authors) (2007) Pollination and other ecosystem services produced by mobile organisms: a conceptual framework for the effects of land-use change. Ecol. Lett. 10: 299-314.

Kus, B. E. (1998) Use of restored riparian habitat by the endangered least Bell's vireo 
(Vireo bellii pusillus). Restor. Ecol. 6: 7582.

Latta, S. C. (2003) Effect of scaly-leg mite infestations on body condition and site fidelity of migratory warblers in the Dominican Republic. Auk 120: 730-743.

Luck, G. W., et al. (2I authors) (2009) Quantifying the contribution of organisms to the provision of ecosystem services. Bioscience 59: 223-235.

Manly, B. F. J., McDonald, L. L., Thomas, D. L., McDonald, T. L. and Erickson, W. P. (2002) Resource selection by animals: Statistical design and analysis for field studies. Dordrecht: Kluwer Academic Publishers.

Murphy, M. T., Pierce, A., Shoen, J., Murphy, K. L., Campbell, J. A. and Hamilton, D. A. (2001) Population structure and habitat use by overwintering neotropical migrants on a remote oceanic island. Biol. Conserv. 102: 333-345.

Pyle, P. (1997) Identification guide to North American birds, Part 1. Bolinas, California: Slate Creek Press.

Reitsma, L., Hunt, P., Burson, S. L. and Steele, B. B. (2002) Site fidelity and ephemeral habitat occupancy: Northern Waterthrush use of Puerto Rican black mangroves during the nonbreeding season. Wilson Bull. 114: 99-105.

Rubenstein, D. R., Chamberlain, C. P., Holmes, R. T., Ayres, M. P., Waldbauer, J. R., Graves, G. R. and Tuross, N. C. (2002) Linking breeding and wintering ranges of a migratory songbird using stable isotopes. Science 295: 591-593.
Sauer, J. R., Hines, J. E, and Fallon, J. (2001) The North American breeding bird survey, results and analysis 1966-200o. Version 2001.2. Laurel, MD: U.S. Geological Survey, Patuxent Wildlife Research Center.

Sekercioglu, C. H., Loarie, S. R., Brenes, F. O., Ehrlich, P. R. and Daily, G. C. (2007) Persistence of forest birds in the Costa Rican agricultural countryside. Conserv. Biol. 21: 482-494.

Smith, A. M., Reitsma, L. R., Rockwood, L. L. and Marra, P. P. (2008) Roosting behavior of a Neotropical migrant songbird, the Northern Waterthrush Seiurus noveboracensis, during the non-breeding season. J. Avian Biol. 39: 460-465.

Stacier, C. A. (1992) Social behavior of the Northern Parula, Cape May Warbler, and Prairie Warbler wintering in secondgrowth forest in southwestern Puerto Rico. Pp. 309-320in J. M. Hagan and D. W. Johnston, eds. Ecology and conservation of Neotropical migrant landbirds. Washington DC: Smithsonian Institution Press.

United Nations Statistics Division (2010) World statistic pocketbook (2008 data for GNI). New York City: United Nations. Available from http://data.un.org/CountryProfile.aspx? crName $=$ Jamaica (accessed September 2010).

Warkentin, I. G. and Morton, E. S. (1995) Roosting behavior of Prothonotary Warblers in the nonbreeding season. Wilson Bull. 107: $374-376$.

\section{VITEK JIRINEC*, BRENT R. CAMPOS, MATTHEW D. JOHNSON}

Department of Wildlife, Humboldt State University, I Harpst Street, Arcata, CA 95521, USA.

${ }^{*}$ Author for correspondence; e-mail: vj2@humboldt.edu

Received 6 April 2010; revision accepted 25 September 2010; Published online 11 February 2011 